\title{
THE PEATLAND RESTORATION AGENCY'S ECONOMIC REVITALIZATION PROGRAM IN ACHIEVING THE TRANSBOUNDARY HAZE-FREE ASEAN 2020 IN RIAU PROVINCE
}

\author{
${ }^{1}$ Yusnarida Eka Nizmi, ${ }^{1}$ Yessi Olivia, ${ }^{1}$ Umi Oktyari Retnaningsih, ${ }^{1} \mathrm{M}$. Saeri, ${ }^{1} \mathrm{Ahmad}$ Jama'an, ${ }^{2}$ Alfajri \\ ${ }_{1}^{1}$ Department of International Relation, University of Riau, Indonesia \\ ${ }^{2}$ Department of International Relation, Abdurab University, Indonesia
}

Corresponding Author: Yusnarida Eka Nizmi E-mail: eka.nizmi@lecturer.unri.ac.id

\begin{tabular}{|c|c|}
\hline ARTICLE INFO & ABSTRACT \\
\hline $\begin{array}{l}\text { Received: } 06-08-2021 \\
\text { Accepted: } 26-10-2021 \\
\text { Published: } 30-10-2021 \\
\text { Volume: } 4 \\
\text { Issue: } 2 \\
\text { DOI: } \\
\text { https://doi.org/10.33019/berumpun.v3i1.61 } \\
\text { KEYWORDS }\end{array}$ & $\begin{array}{l}\text { This study analyses the implementation of good governance } \\
\text { principles for the economic revitalization program under the } \\
\text { supervision of Riau Province's Badan Restorasi Gambut } \\
\text { (Peatland Restoration Agency). One of the aims of this } \\
\text { program is to support the haze-free ASEAN } 2020 \text { roadmap. } \\
\text { Riau province is an area prone to forest fire disasters. Its } \\
\text { peatlandarea, which is larger than Malaysia's total peatlands, } \\
\text { have a very high potential for damage due to forest fires. To }\end{array}$ \\
\hline $\begin{array}{l}\text { Forest fires, wildfiremitigation, economic } \\
\text { revitalization, haze free ASEAN2020, Peatland } \\
\text { RestorationAgency, }\end{array}$ & $\begin{array}{l}\text { mitigate the damages, BRG initiated the } 3 R \text { program: } \\
\text { Rewetting, Revegetation, and Revitalization. What makes this } \\
\text { topic interesting is BRG emphasizes the aspects of economic } \\
\text { empowerment of local communities to prevent further forest } \\
\text { and peatland damages. To assess the implementationof BRG's } \\
\text { program, our research team conducted several interviews with } \\
\text { representatives from Indonesia's Ministry of Environment and } \\
\text { Forestry, NGOs, academics, farmers, and villages' facilitators } \\
\text { who assisted local communities that received the BRG's } \\
\text { assistance packages. Our study shows that BRG's economic } \\
\text { revitalization program had succeeded in creating small scale } \\
\text { economicactivities such as honey industry, pineapple farming, } \\
\text { and catfish farming. However, the ineffective coordinationand } \\
\text { communication between BRG and the local communities had } \\
\text { prevented them from constructing an effective method to } \\
\text { prevent futureforestfires. }\end{array}$ \\
\hline
\end{tabular}

\section{INTRODUCTION}

In response to severe haze pollution emitted from land and forest fires in 1997-98, member countries of Association of Southeast Asian Nations (ASEAN) pledged to cooperate to "prevent, monitor, and mitigate land and forest fires" under the ASEAN Agreement on Transboundary Haze Pollution (AATHP) (ASEAN, 2018). While haze problems had plagued the region before the 1997-98 crisis, it was only after a public backlash that ASEAN member countries finally agreed to produce their first legally binding agreement on environmental issue. Under AATHP, ASEAN admitted that a regional collaboration to address the recurring 
problem is crucial. Several mechanisms and procedures were introduced, such as the Coordinating Centre for Transboundary Haze Pollution Control (ACC THPC), the Conference of the Parties (COP) to the ASEAN Agreement on Transboundary Haze Pollution, and the Roadmap on ASEAN Cooperation towards Transboundary Haze Pollution Control with Means of Implementation.

Indonesia, the epicenter of forest fire in the region, ratified AATHP in 2014, 12 years after its adoption. Indonesia's economic interest from oil palm industry is said to be the main reason of Indonesia's delaying the ratification (Varkkey, 2014). Since the 1997-98 crisis, forest fire has been a constant problem and a source of embarrassment for Indonesia. The 2007 wildfire, for example, forced president Susilo Bambang Yudhoyono to apologize to Malaysia and Singapore in public due to the heavy smog that the country exported (Maharani, 2013). The haze produced from Indonesian forest fire has also become a lifethreatening issue as the pollution reaches a hazardous level. In the 2013 forest fire, for example, Singapore recorded the highest read of 401 PSI coming from the haze that engulfed the country (BBC, 2013).

Joko Widodo, who was elected as the seventh Indonesia's president in 2014, took a series of effort to tackle forest fire from merging the Ministry of Forestry and Ministry of Environment to establishing established Badan Restorasi Gambut (Peatland Restoration Agency) in 2016 (Varkkey, 2017). The creation of BRG coincided with the $12^{\text {th }}$ meeting of the COP to ASEAN AATHP where ASEAN introduced the roadmap that aims for a haze-free ASEAN by 2020 (ASEAN, 2018). BRG's main program to restore peatlands destroyed by wildfire is known as Strategi $3 R$ (3R strategy): rewetting, which is taking several measures to boost the wetness of the peatlands; revegetation, which is replanting trough nursery and natural regeneration; and revitalization, which is improving the community welfare through agriculture, fisheries, and ecotourism (BRG, n.d.)

The focus of this study is the revitalization from BRG's Strategi $3 R$ in Riau Province. According to Indonesia's forest and land fire control system, SiPongi, between 2015 to 2020, land and forest fires still rage Riau Province (KLHK, n.d.). As a province where its peatlands are larger than Malaysia's total peatlands (CIFOR, n.d.) this study presents an interesting 
case study on the realization of BRG's program. Thus, this study looks at the implementation of good governance principles for the economic revitalization program under the supervision of Riau Province's BRG. Through interviews with several respondents from the government, NGOs, village's facilitators, the study shows that while the logic behind the program is sound, the ineffective cordination and communication between BRG and the local communities prevents them constructing an effective method to prevent future forest fires.

Good governance as a popular concept in preventing future forest fires has various explanations. The concept of good governance which first popularized by institutions such as the World Bank in regard to development assistance (Nanda, 2006). Bjork and Johansson (2001) argue that modern forms of government is not only related to efficiency but also the arrangement of accountability between the state and its citizens. Some of the principles of good governance include aspects of accountability, control, responsiveness, transparency, public participation, economics, efficiency, and so on (Minogue, Polidano, and Hulme, 1998). Other international organizations, such as the International Monetary Fund (IMF) (2012), summarized that good governance must include aspects of the rule of law, improving efficiency and accountability of the public sector, and combating corruption. This research applies the concept of good govenance from UNDP version of good governance since it has provided a thorough rationalization of the concept

\section{LITERATURE REVIEW}

The United Nations Development Program (UNDP) (2007) underlined the important features of good governance, including participation, rule of law, transparency, responsiveness, consensus, fairness and inclusiveness, efficiency and effectiveness, and accountability. Participation is the first important principle in good governance. It requires the involvement of citizens in the political process where it is upheld that every adult should have a voice in the decision-making process, either directly or indirectly through their representatives in the parliament (Osmani, 2007; Rotberg, 2004). The second principle in good governance is rule of law that guarantees equality and justice. This principle emphasizes individual rights, independent judiciary, and impartial security forces (Harrison, 2005; Moloney, 2009; Sheng, n.d.). 
The third principle is transparency. This principle states that the availability of adequate information that is widely and freely distributed through various media channels that can be directly understood by the people who will be affected can strengthen the realization of compliance (Sheng, n.d.). To ensure good governance practices, government policies must be of good quality and open to all citizens so that public trust grows. In addition, the decision-making process and final decisions of good governance should be open and subject to multiple audits by either government organs or by independent auditors or other non-governmental organizations (Andrews, 2008; Gisselquist, 2012). The fourth principle of good governance is responsiveness. Responsiveness requires that all institutional processes must be willing and able to provide services to all citizens within a measurable period. Responsiveness requires elasticity to accommodate rapid changes in society by involving civil society in understanding the interests of the general public (Gisselquist, 2012). Responsiveness also means the ability and flexibility of the government to respond and accommodate changes in society (Rotberg, 2004).

The fifth principle of good governance is consensus or mediation between various groups to reach a general agreement, to accommodate various interests and different views (Harrison, 2005; Sheng, n.d.). The sixth principle is fairness and inclusivity. This principle wants to ensure that there is a guarantee of human dignity, equal rights, and freedom from all forms and types of discrimination. Thus, all citizens must have equal access to improve their destiny and improve their welfare(Grindle, 2004; Harrison, 2005).

The seventh principle is efficiency and effectiveness. These are the essential parts of modern management as shown by an abundant literature that talk about the importance of these principles (see: Grindle, 2004; Nanda, 2006; Rothstein \& Teorell, 2008) Kurtz and Schrank, 2007. The last one is accountability. This is considered as the foundation of good governance where its true meaning lies in the responsibility in allocating and using state's resources. Accountability demands the compliance with the law and its requirements (Grindle, 2004; Harrison, 2005) Kurtz and Schrank, 2007. The government, private sectors, and non-profit parties (civil society organizations), according to this principle, must be responsible to the public (Rotberg, 2004; Rothstein \& Teorell, 2008). 


\section{METHODOLOGY}

This research is qualitative study where the primary data is collected through interviews and observations method. It also relies on secondary data from journal articles, books, reports, media news, and so on. This research interviewed 15 respondents. The respondents for this study are those who involved and participated in BRG's economic revitalization program since 2016. The respondents to be interviewed include multi-actor, starting from the actors of the BRG economic revitalization program in the field (village facilitators), community groups (pokmas), farmers from the RE BRG program, and non-RE BRG, including civil society organizations that focus on dealing with wetlands or peatlands, the government as well as academics.

Data collection techniques used in this study were participant observation and semistructured interviews with informants and relevant sources. Participant observation was conducted to observe the behavior and activities of the actors of the BRG people's economic revitalization program in several locations that have been determined by the researchers. Meanwhile, semi-structured interviews were carried out by looking at the relevance of the informants to the topic being researched.

\section{RESULTS AND DISCUSSION}

\section{Peatland Restoration Agency and the Evaluation of Economic Revitalization Program} Minogue, Polidano, and Hulme (1998) suggest that good governance incorporate the aspects of accountability, control, responsiveness, transparency, public participation, economics, and efficiency. Several parties are directly involved in the implementation of the economic revitalization program (RE) managed by the Peat Restoration Agency: the BRG itself, community groups, village facilitators, farmers. There are also those farmers who were not involved in the RE program, which in the interview were referred to as non-BRG farmers.

\section{The Aspects of Community Participation and Responsiveness}

Several informants we interviewed gave their opinions on the governance handled by BRG related to the ER program. In the context of community participation and responsiveness, 
our informants said that there was no public announcement to be part of this RE program (Interview with respondent 4). Another informant we interviewed added that the villagers knew that their village was the target of the RE program after the selected community groups to handle the RE program (called kelompok masyarakat-pokmas ) were formed. They did not understand at all that the basic requirements were to qualify to become Pokmas (Interview with respondent 8).

A member of the Pokmas said that at that time he was invited by a friend, and in the end, he participated. When asked what caused him to participate in the RE BRG program, it was because a friend invited him (Interview with respondent 6). Proximity to the Pokmas chairman and the BRG is a determinant of whether or not to be involved in the RE BRG program. Of course, this condition can be questioned whether their involvement in RE BRG program activities is really based on their expertise or just for reasons for personal closeness.

One of the chiefs in the Medang sub-district we interviewed informed us that he knew that there was indeed a RE BRG program in his sub-district area but only knew about it. Not in detail, because it was never officially informed about its development (Interview with respondent 7).

\section{The Aspects of Transparency and Accountability}

Aspects of the RE BRG program were part of the questions in the interviews that were posed to informants. Several village facilitators from different community groups said they reported every activity or program they had carried out (some in the shrimp farming sector, catfish farms, pineapple plantations, and honey farms) in their respective working areas to the Central BRG. (Interview with respondent 5). Central BRG management also visited their area to discuss various issues related to the challenges and obstacles in implementing the RE work program (Interview with respondent 5).

The determination of what Economic Revitalization program is considered to be developed in an area/village is part of the questions asked to informants to find out how the aspects of transparency and accountability are implemented. The answer from a sub-district staff who is also a member of the Community Care (MPA) emphasized that the RE BRG program in Medang Kampai sub- 
district is almost the same, and it is not known what reasons or considerations were the basis for choosing the RE program in a village.

\section{The Aspects of Justice and Inclusiveness}

With the aspect of justice and inclusivity to the RE BRG program, several village facilitators gave their opinions. A village facilitator said that for gender justice, in their community group and work areas they are always in the core management, both secretaries and treasurers (Interview with respondent 9). Even the head of community group (Pokmas) in the RE Program from BRG is a woman (Interview with respondent 10). So, from the point of view of the community group (Pokmas) and village facilitators in terms of equity and inclusivity, this is going quite well. There is no difficulty for certain genders to be part of the village facilitators who will assist selected villages in the Economic Revitalization program managed by the Peat Restoration Agency (Interview with respondent 11).

However, when we asked the same question to non-BRG farmers (not part of the REBRG program), it can be seen that the members of the BRG Pokmas are people who have connections to the Central BRG management (patronage politics), so from this point of view, the aspects of justice and inclusiveness are very low (Interview with respondent 4).

We received a similar answer from a Medang sub-district staff who emphasized that the ward did not know the mechanism for recruiting members. There was no official recruitment announcement, nor was he aware of the selection patterns that were open to the public or the type of competency assessment that became the standard. This information is unknown to him (Interview with respondent 6).

\section{The Aspect of Sustainability}

Talking about the implementation of sustainability aspects, several RE programs can be said to be successful, such as what happened in Penampi and Kelebuk villages, but some have failed. Penampi Village is a village whose territory is on the sea coast of Bengkalis Island. The Peat Restoration Agency (BRG) listed Penampi village as a target village for restoration in Indonesia for the restoration of the peat ecosystem to occur in 2019. Results of interviews with the Penampi community regarding their perceptions of the peat restoration program, there are various perceptions. Some people say that the program is to improve the usability 


\section{BERUMPUIN}

International Journal of Social, Politics, and Humanities

https://berumpun.ubb.ac.id/index.php/BRP

and fertility of the soil, some say that this program is part of a method to avoid land fires (Interview with respondent 1).

A visit to Penampi village to see first-hand the implementation of the BRG Economic Revitalization program specifically for Kelulut honey cultivation, which is famous for managing honey without worrying about bee stings, can be said to be successful. Samsur, a honey farmer who was involved as a participant in the RE program, said that this program had a positive impact on the economy of the Penampi community's family (Interview with respondent 2).

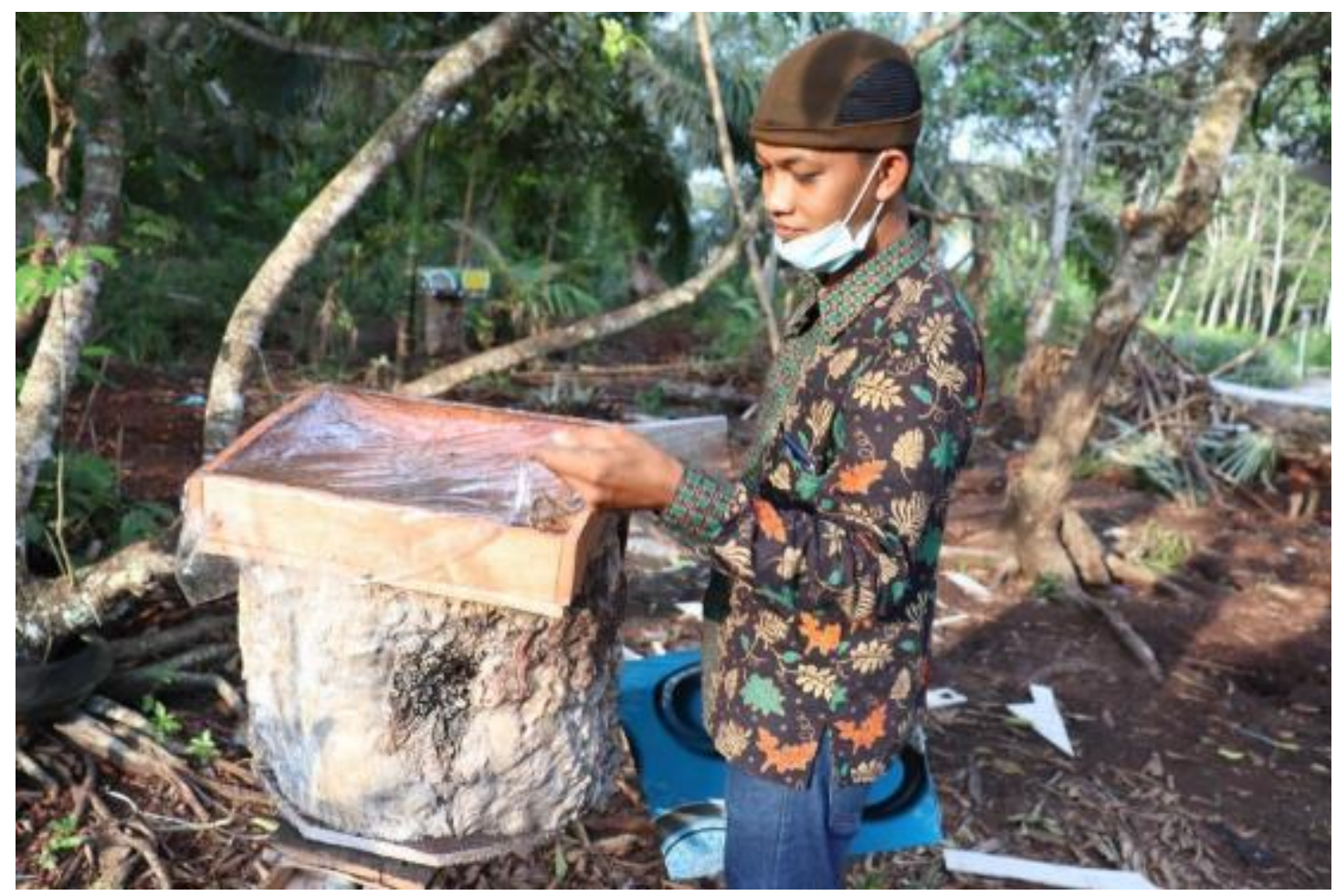

Figure 1 Samsur showing the process of breeding kelulut honey 


\section{BERUIMPUIN}

International Journal of Social, Politics, and Humanities

https://berumpun.ubb.ac.id/index.php/BRP

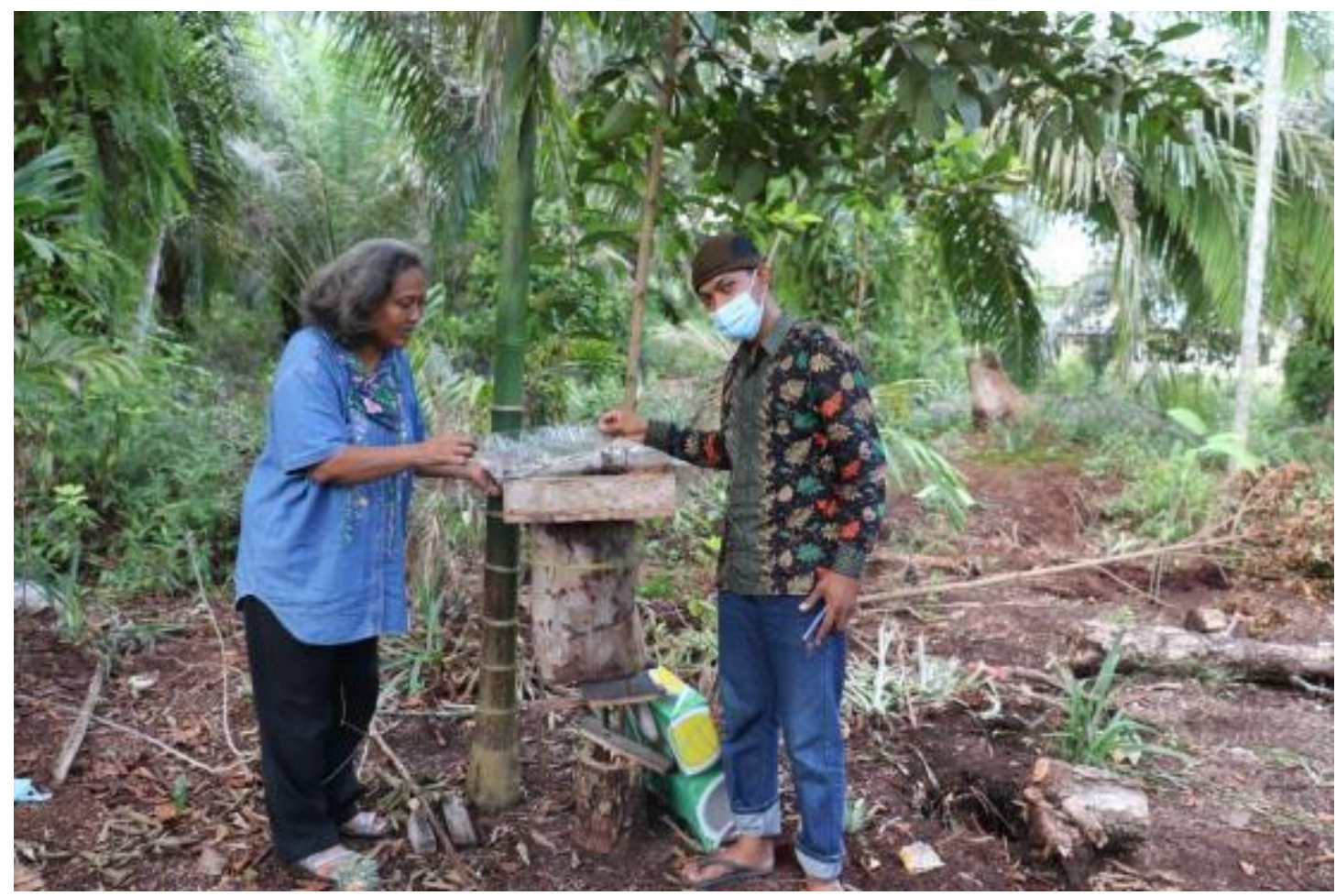

Figure 2 Kelulut honey farmer

Other farmers who are also involved in the kelulut honey cultivation program, also said that the RE BRG honey program has a fairly high sustainability aspect for the community. Another RE BRG program that is said to have a good sustainability aspect is the RE BRG program in Mundam sub-district with its shrimp ponds still running. The first year was successful, the second year suffered a little loss due to feed problems, but in the third year, the shrimp farming program was running again and did not face any significant problems. 


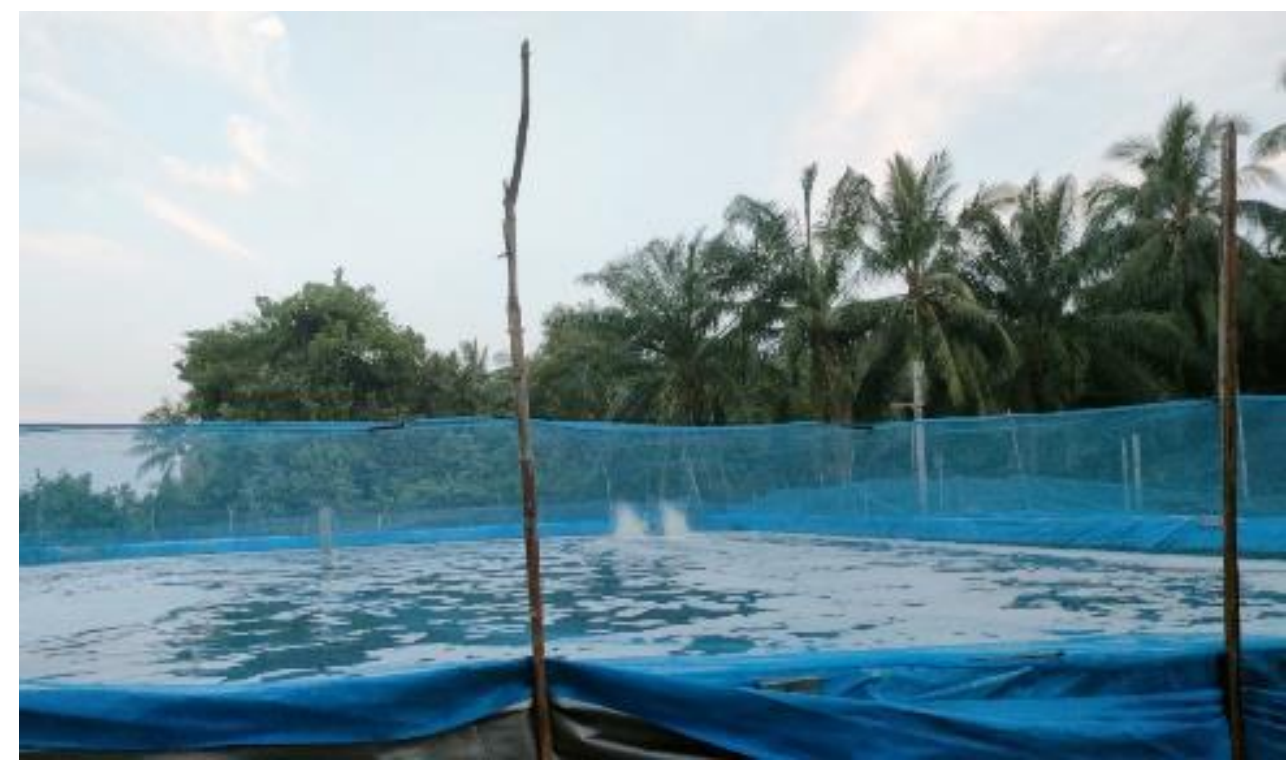

Figure 3 Shrimp cultivation program

Field observations and interviews with several informants regarding the sustainability aspects of the catfish farming RE program in Teluk Makmur Village can be said to have failed. The Pokmas Lele program took place around 2017-2018. What remains is only the former catfish breeding grounds in the form of land seminization behind an informant's house. The informant also said that in his village there was also an RE program for chicken farming, which also failed and the program did not continue. 


\section{BERUMPUN}

International Journal of Social, Politics, and Humanities

https://berumpun.ubb.ac.id/index.php/BRP

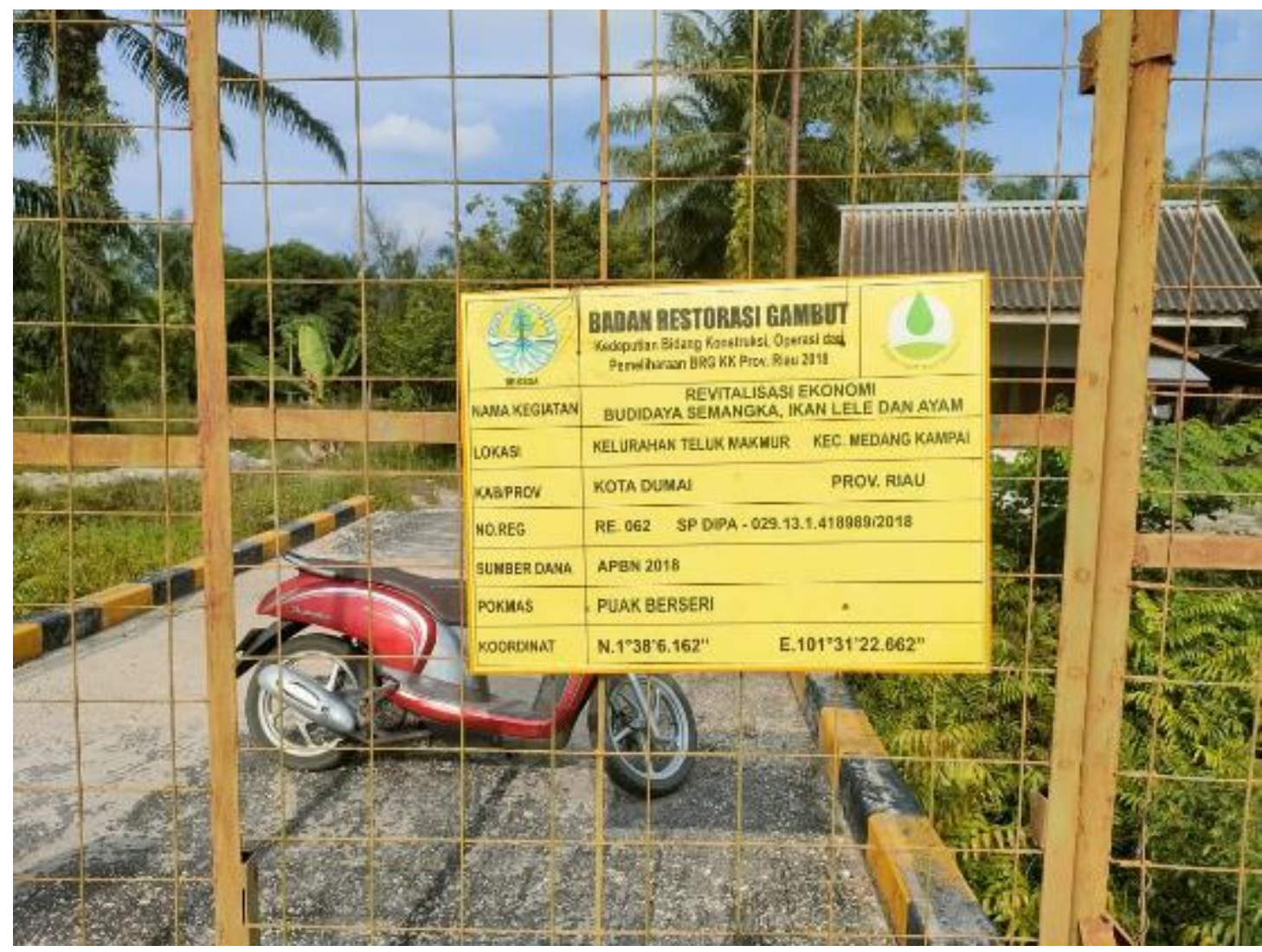

Figure 4 Front view of BR program

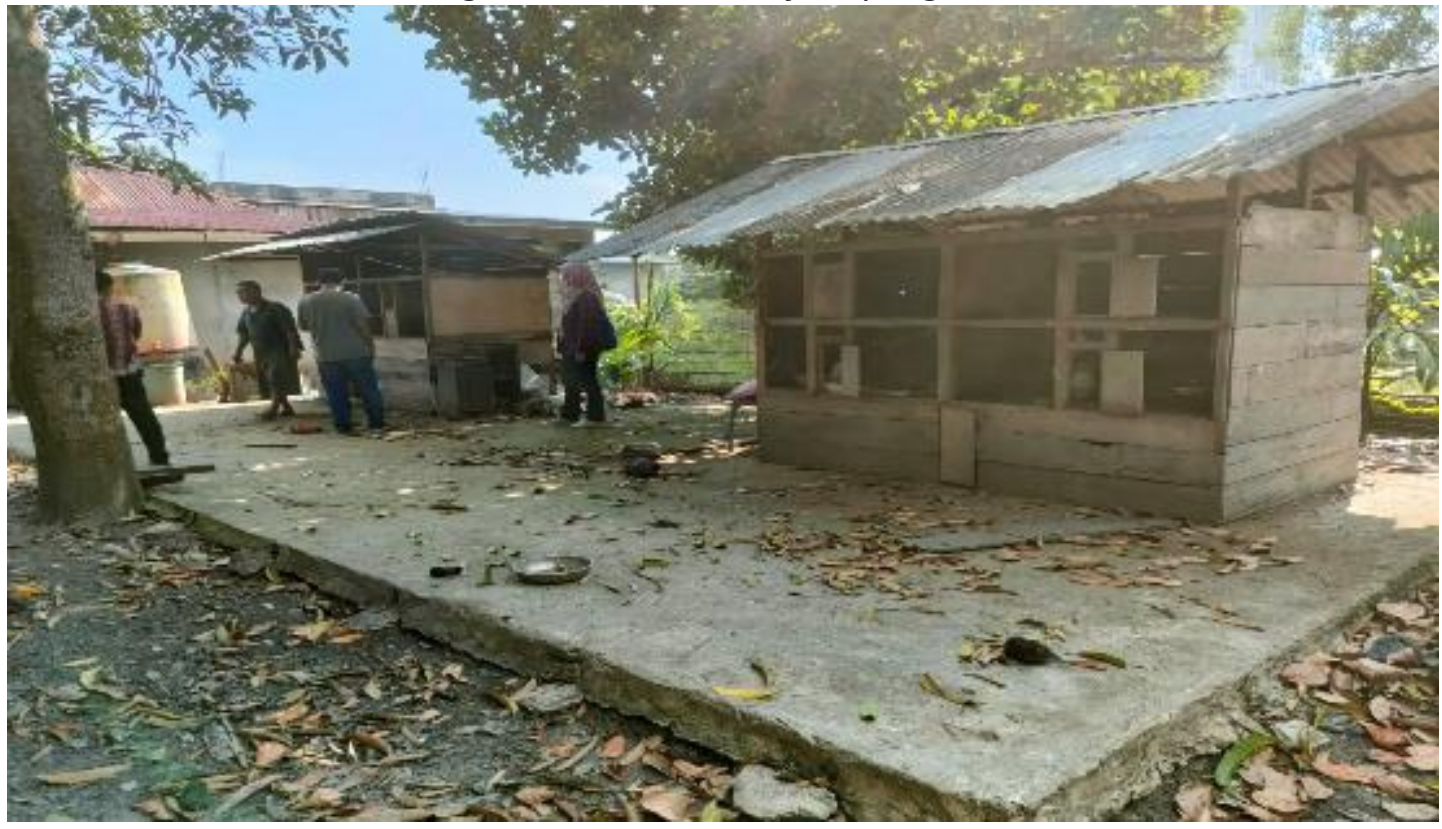

Figure 5 Chicken farm in Teluk Makmur Village, Medang Kampai, Dumai 
BERUIMPUIN

International Journal of Social, Politics, and Humanities

https://berumpun.ubb.ac.id/index.php/BRP

The sustainability of the pineapple cultivation program in Mundam Village was also not found. This can be seen from the team's observations in the field and interviews with nonBRG farmers. He said that the RE BRG program only runs for the first year, the next year its seems that it will no longer run if there is no new budget that is dropped (Interview with respondent 4). Pineapple plantations, as seen in the photo below, only see shrubs that are very vulnerable to land fires, while the pineapple trees are no longer maintained.

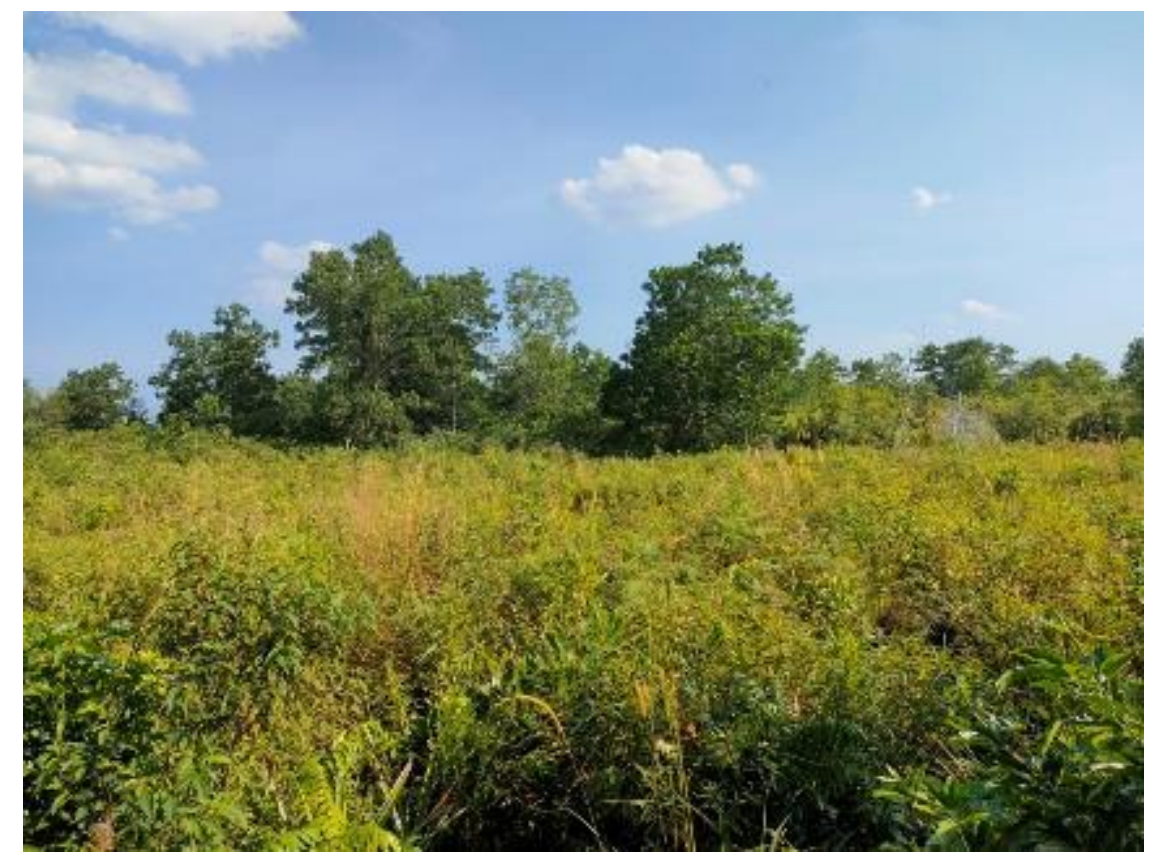

Figure 6 An abandoned pineapple farm

\section{The Aspects of Law Supremacy Enforcement}

Aspects of the enforcement of the rule of law became part of the issues we asked the informants about. We got the answers they do not understand the rule of law well. Because they said that when the RE BRG program failed, as happened at the Tanjung Palas Pokmas were of the total 60 goats provided by BRG, there were only 3 left, the remaining 57 there was no explanation as to whether they died of illness because there were no photos or evidence from cow graves (Interview with respondent 5). This includes catfish and chicken farming in Teluk Makmur Village which failed, but the informants did not know or could not explain anything about the aspect of the rule of law. 


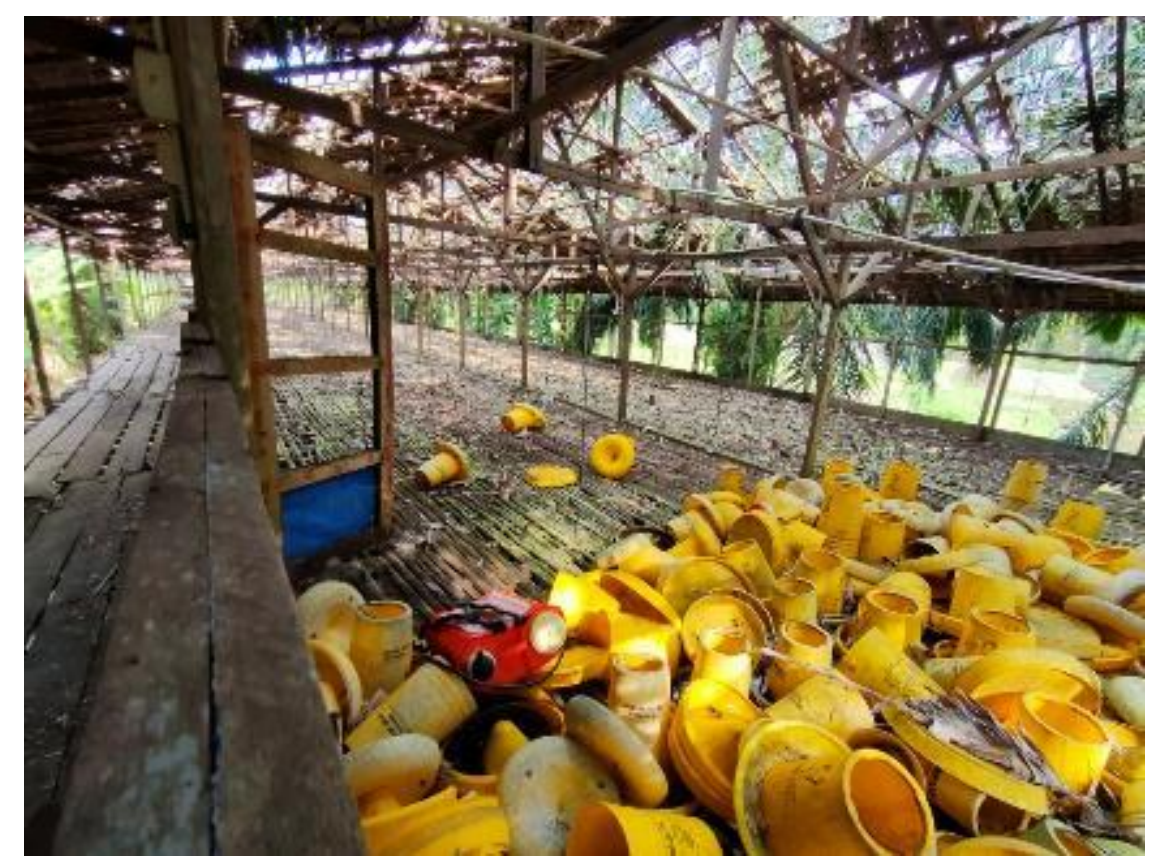

Figure 7 An abandoned chicken farm

\section{The Effectiveness and Efficiency of the RE BRG Program on Forest Fire Prevention The}

The issue that is also a concern in this study of the RE BRG Program is how the effectiveness and efficiency of the RE program on forest fire prevention is. From some of the answers obtained, it can be emphasized that this is very dependent on the sustainability of the program or the success or failure of the program being implemented. As stated by one of the informants, if the program and its budget do not continue or the program fails and is stopped, then the chance of a fire is still high (Interview with respondent 4). The forest fires that occurred in 2020 still occurred not far from the BRG pineapple plantation RE program where there was about 10 ha of burned land. This proves that the effectiveness and efficiency of the RE BRG Program can still be said to be the lowest. 


\section{BERUMPUN}

International Journal of Social, Politics, and Humanities

https://berumpun.ubb.ac.id/index.php/BRP

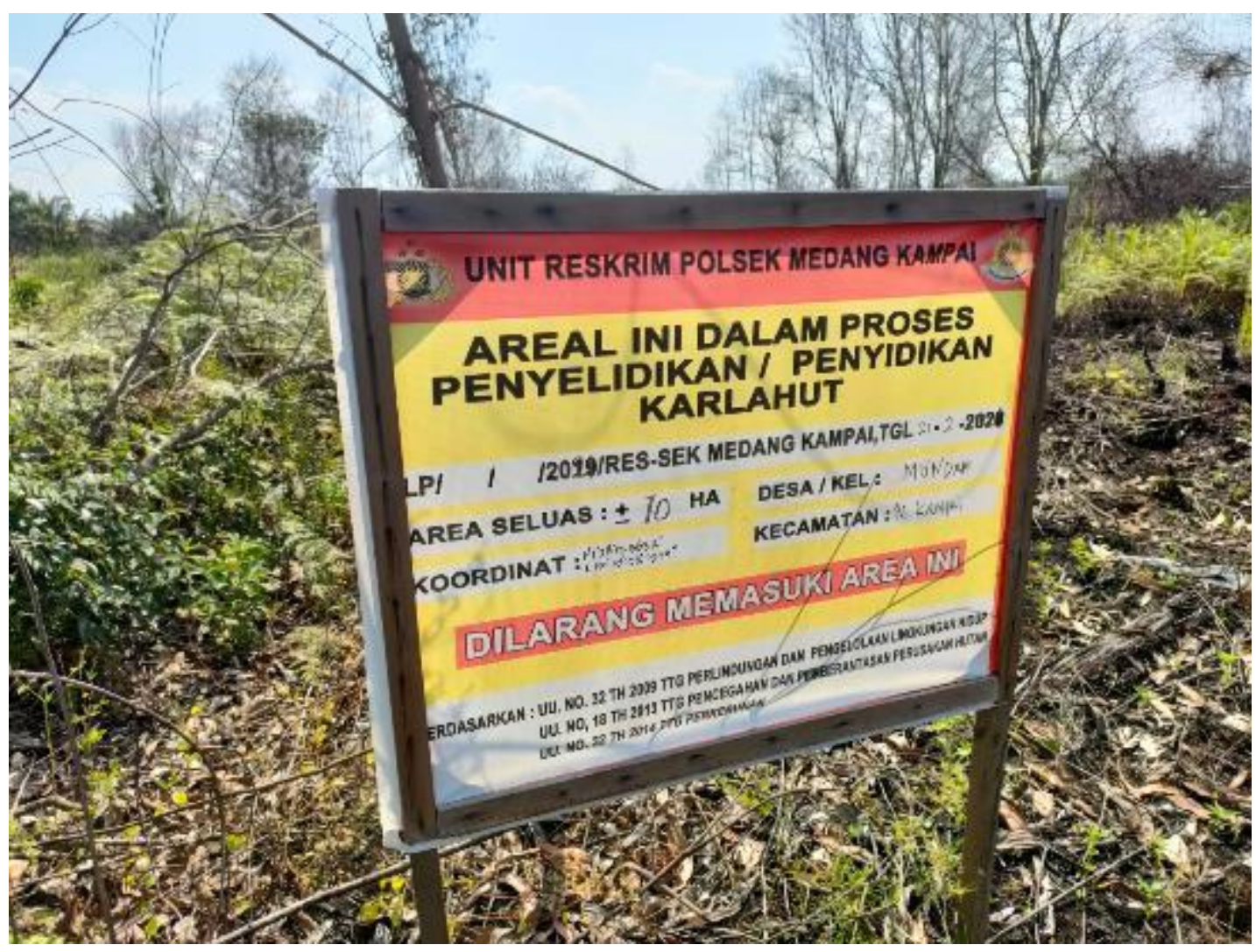

Figure 82020 forest fire area around the RE BRG program pineapple plantation

\section{CONCLUSION}

This research has evaluated the BRG's program through the good governance principles such as participation, transparency, responsiveness, accountability, fairness and inclusiveness, efficiency and effectiveness as well as the rule of law. It has shown that the realization of the BRG program has not yet meet the criteria of good governance principles. As a result its contribution to haze-free ASEAN by 2020 was insignificant.

This study suggests the need for a balance between the aspects of demand and support and the importance of multi-actor or multi-stakeholder involvement in achieving the haze-free ASEAN. These actors are called ABC-GIM, namely those involved in the Academic, Business, sectors. Civil Society Organizations, Government (Government), Individual-Influencers and Media. The involvement of this multi-actor needs to be considered in its implementation to ensure the creation of good governance in the Economic 
Revitalization program carried out by the Peat Restoration Agency so that Haze Free ASEAN can be achieved.

\section{ABOUT THE AUTHORS}

The authors are a group of researchers coming from Universitas Riau and Universitas Abdurrab in Pekanbaru.

\section{REFERENCES}

Andrews, M. (2008). The good governance agenda: Beyond indicators without theory. Oxford DevelopmentStudies, 36(4), 379-407.

ASEAN. (2018, February 4). About ASEAN Cooperation on Transboundary Haze Pollution Control. ASEAN Cooperation on Environment. https://environment.asean.org/aboutasean-cooperation-on-transboundary-haze-pollution-control /

BBC. (2013, June 21). Singapore haze hits record high from Indonesia fires-BBC News. https://www.bbc.com/news/world-asia-22998592

Björk, P. G., \& Johansson, H. (2001). Towards governance theory: In search for a common ground. IPSA Papers.

BRG. (n.d.). Strategi 3R dalam Upaya Restorasi Gambut - BRGM Indonesia. Retrieved October 24, 2021, from https://brg.go.id/strategi-3r-dalam-upaya-restorasigambut/

CIFOR. (n.d.). Global Wetlands. Retrieved October 24, 2021, from https://www2.cifor.org/global-wetlands/

Gisselquist, R. M. (2012). Goodgovernance as a concept, and why this matters for development policy. WIDER Working Paper. 
Grindle, M. S. (2004). Good enough governance: Poverty reduction and reform in developing countries. Governance,17(4), 525-548.

Harrison, G. (2005). The World Bank, governance and theories of political action in Africa. The British Journal of Politics and International Relations, 7(2), 240-260.

KLHK. (n.d.). SiPongi-Karhutla Monitoring Sistem. Retrieved October 24, 2021, from http://sipongi.menlhk.go.id/home/main

Maharani, E. (2013, June 24). Presiden Minta Maaf ke Singapura dan Malaysia, Menteri Telan Ludah | Republika Online. Republika. https://www.republika.co.id/berita/nasional/umum/13/06/24/mowl7o-presidenminta-maaf-ke-singapura-dan-malaysia-menteri-telan-ludah

Moloney, K. (2009). Public administration and governance: A sector-level analysis of World Bank aid. International Review of Administrative Sciences, 75(4), 609-627.

Nanda, V. P. (2006). The "good governance" concept revisited. The ANNALS of the American Academy of Political and Social Science, 603(1), 269-283.

Osmani, S. (2007). Participatory governance for efficiency and equity: An overview of issues and evidence. Background Paper Prepared for the World Public Sector Report.

Rotberg, R. I. (2004). Strengthening governance: Ranking countries would help. The Washington Quarterly, 28(1), 71-81.

Rothstein, B., \& Teorell, J. (2008). What Is Quality of Government? A Theory of Impartial Government Institutions. Governance,21, 165-190.

Sheng, Y. K. (n.d.). What is Good Governance. UNESCAP. https://www.unescap.org/sites/default/files/good-governance.pdf 
BERUMMUIN

International Journal of Social, Politics, and Humanities

https://berumpun.ubb.ac.id/index.php/BRP

Varkkey, H. (2014). Regional cooperation, patronage and the ASEAN Agreement on transboundary haze pollution | SpringerLink. International Environmental Agreemts: Politics, Law and Economics, 14, 65-81.

Varkkey, H. (2017). "In 3 Years We Would Have Solved This": Jokowi, ASEAN and Transboundary Haze. Jurnal Studi Pemerintahan, 8(3), 277-295. 